\title{
Attitudes of Residents Toward Street Trees on Four Streets in Toledo, Ohio, U.S. Before Removal of Ash Trees (Fraxinus spp.) from Emerald Ash Borer (Agrilus planipennis)
}

\author{
Joseph Heimlich, T. Davis Sydnor, Matthew Bumgardner, and Patrick O'Brien
}

\begin{abstract}
Toledo, Ohio, U.S. residents on four streets in an area with mature street trees, including ash, scheduled for removal as a result of attack by emerald ash borer were surveyed to determine their attitudes toward their street trees. Toledo is in the process of removing some 5,000 trees. Large trees with a variety of summer and fall foliar characteristics were highly valued suggesting that residents would be satisfied with a mix of species rather than planting each street to a single species. The fact that their trees canopied the street was also important to residents and is characteristic of larger urban trees. Residents would be pleased if replacements were planted before removing existing trees. Flowers were not a significant concern for residents. In Toledo, as it is in many communities, the primary maintenance concern regarding trees in this survey is the potential damage to sidewalks.

Key Words. Agrilus; ash replacements; community safety; emerald ash borer; Fraxinus spp.; green ash; resident attitudes; street trees.
\end{abstract}

Emerald ash borer $(\mathrm{EAB})$ is a recently introduced exotic pest from Eastern Asia (Akiyama and Ohmomo 2000; Poland and McCullough 2006). The insect was first described in the Detroit, Michigan, U.S. area in 2002 (United States Department of Agriculture, Animal Plant Health Inspection Service 2003; Cappaert et al. 2005). Currently, these pests are found in Michigan, northwestern Ohio, and northeastern Indiana (Herms et al. 2004). These pests are in the order Buprestidae and are known as buprestids or metallic wood-boring beetles.

Emerald ash borer outlier populations have spread more rapidly than at first predicted (Cappaert et al. 2005; Iverson et al. 2006). Because the EAB is an exotic insect, there is no evolutionary history for this pest with the native North American ashes and thus the insect is very likely to kill its host. The latent period when the plants are asymptomatic has only recently been studied (Cappaert et al. 2005). Although plants decline and die rapidly on becoming symptomatic, failure to account for the latent period results in the appearance that the insect takes longer to kill its host than originally thought. This is a problem because early infestations are difficult to diagnose and several life cycles can be completed before a landowner might be expected to identify the threat. Currently, all of Toledo's approximately 5,000 ash street trees are scheduled for removal. This task began in June 2006. Statewide, the total losses for removal and replacement could range from $\$ 1.8$ to $\$ 7.8$ billion in Ohio communities alone (Sydnor et al. 2007).

Researchers visited an area in Toledo, Ohio, in early June 2006 where trees were scheduled for removal approximately 1 month later as a result of an EAB infestation. A number of residents came out to check and see what was happening in their neighborhood. Several residents offered suggestions. One resident reminded us that the ash trees to be removed had been planted in response to the removal of elm trees in the 1950s. His question was "Don't we ever learn?" It is interesting that Cheng and McBride (2006) noted that after the World War II devastation in Hiroshima and Tokyo, there was a tendency by the public to initially recreate what had been and to reject urban planning.
It was clear that residents of Toledo had something to say. The city in turn wanted the residents to feel that their wishes were being heard and that the city was responsive. The survey was considered a good way to gain citizen input as has been demonstrated in other cities such as Sacramento (Sommer et al. 1989).

\section{BACKGROUND}

A number of studies have been conducted to assess resident attitudes over the years in nearby states and provinces. Cultural backgrounds have been shown to result in differing attitudes toward trees (Fraser and Kenney 2000; Johnston and Shimada 2004; Schroeder et al. 2006). Schroeder et al. noted that Chinese, Portuguese, Italian, and U.K. residents had differing attitudes toward shade trees but preferred fewer or smaller trees. Hitchmough and Bonugli (1997) noted that Scottish residents also preferred smaller trees and further noted that females had stronger preferences for reduced plantings or smaller trees. This is in contrast with surveys of U.S. residents (Kalmbach and Kielbaso 1979; Schroeder and Cannon 1983; Sommer et al. 1989; Schroeder, and Ruffolo 1996; Schroeder et al. 2006) where larger trees were preferred.

Schroeder and Ruffolo (1996) noted that the single largest factor in determining the attractiveness of street scenes was the size of trees and that streets were especially attractive when larger trees canopied the street. In one study, virtually no one rated their trees as too small when asked whether their trees were too small or too large (Schroeder and Ruffolo 1996). This was true even when the individual had expressed a preference for smaller trees.

Interestingly, the preference for larger trees in an aesthetic sense is in keeping with studies maximizing ecological benefits of trees. Large trees delivered more benefits to include increased or improved shading, water quality, and air quality (McPherson 2005). Similarly, social benefits accrue to larger trees and grass in inner cities (Kuo 2001). 
Communities have normally been planted with a single taxa on a given street. Would residents prefer to go back with single taxa or would residents tolerate or prefer a variety of street trees on their street? Additionally, there has been a tendency to plant medium to small street trees in recent years. Would residents prefer larger trees as replacements as recommended by McPherson (2005)? Studies have shown that "experts" and residents often have different ideas of what is desired or constitutes a desirable planting (Bonnes et al. 2004).

Thus, it was decided to determine what residents value about their neighborhood and trees before the removal of the ash trees. The intent was to use the information to assist communities in Ohio, especially Toledo, with ash replacement strategies.

\section{MATERIALS AND METHODS}

Socioeconomic status has been demonstrated as a factor that affects attitudes toward street or park trees (Martin et al. 2004). Additionally, this was seen as a factor in the review by Bonnes et al. (2004). A site visit was made to view the Toledo area where 131 larger ash trees were infested with EAB and scheduled for removal. Four-block segments of four north-south streets were selected for study. The study area was an established, middle class area in northern Toledo dominated by single-family residences. In Toledo, larger ash trees were concentrated in neighborhood constructed between 1950 and 1965 . These areas are relatively uniform in socioeconomic status. The sample area was not chosen randomly, but to assess impacts from EAB in an established neighborhood with larger trees. Thus, results should not be extrapolated to Toledo as a whole with its diverse areas such as commercial districts.

Streets were generally canopied by mature [less than $38 \mathrm{~cm}$ (15.2 in)] street trees in 1.2 to $1.8 \mathrm{~m} \mathrm{(3.96} \mathrm{to} 5.94 \mathrm{ft})$ tree lawns. Two streets were selected because they were dominated by ash trees and the streetscape would be altered when the trees were removed, whereas two streets were dominated by other species in the tree lawns and would remain unchanged. The study area was not known to be dominated by any specific ethnic group; thus, ethnicity was not evaluated. Trees had been marked for removal and residents had been notified of their impending removal before the distribution of the survey. A mail survey was used to enable a larger percentage of residents to respond. The city mailed the survey forms so that the researchers would not be involved in selecting participants plus the city felt that this would be an expression that they were concerned about residents and their attitudes.

The survey instrument (Appendix 1) covered both sides of an $8.5 \times 11$ inch sheet of paper. A cover letter was prepared asking for citizen support and reminding them that their response was anonymous but that it might help other Ohioans because Toledo was the first of Ohio's major communities hit by this newly introduced pest. The survey instrument was divided into one general area, and four subject areas covering feelings about the street or neighborhood, the trees on the street, assets of trees, and concerns about trees. Survey questions can be seen in Tables 1-4. Additionally, a summated mean was derived by averaging an individual's responses to the various questions within a topic area. Ohio State's Institutional Review Board approval was obtained for the study.

The Division of Forestry for Toledo addressed and mailed the survey instrument with the cover letter and a postage-paid, selfaddressed envelope to all addresses in the city mailing list on the
Table 1. Residents were questioned how important each of the reasons was to them in terms of how well they liked the street on which they lived. ${ }^{z}$

\begin{tabular}{|c|c|c|c|c|}
\hline Reasons & Mean $^{y}$ & $\begin{array}{l}\text { Standard } \\
\text { deviation }\end{array}$ & Median & Mode \\
\hline Feeling safe & 6.67 & 0.83 & 7 & 7 \\
\hline The cleanliness of the street & 6.32 & 0.71 & 6 & 7 \\
\hline The attractiveness of the street & 6.27 & 0.72 & 6 & 7 \\
\hline The value of the houses & 6.03 & 1.08 & 6 & 7 \\
\hline The mature trees on the street & 6.03 & 1.04 & 6 & 7 \\
\hline $\begin{array}{l}\text { The proximity to necessities } \\
\text { (groceries, stores) }\end{array}$ & 5.94 & 1.18 & 6 & 6 \\
\hline The neighbors & 5.93 & 1.06 & 6 & 7 \\
\hline $\begin{array}{l}\text { Being a good area for children } \\
\text { to play }\end{array}$ & 5.93 & 1.33 & 6 & 7 \\
\hline The amount of traffic & 5.92 & 1.06 & 6 & 7 \\
\hline $\begin{array}{l}\text { The landscaping people have in } \\
\text { front of their houses }\end{array}$ & 5.54 & 1.17 & 6 & 5 \\
\hline $\begin{array}{l}\text { The style of houses/homes/ } \\
\text { apartments }\end{array}$ & 5.44 & 1.27 & 5 & 5 \\
\hline Knowing my neighbors & 5.33 & 1.31 & 5 & 5 \\
\hline Summated mean & 5.91 & 0.59 & & \\
\hline
\end{tabular}

${ }^{\mathrm{z}}$ Answers are ranked from highest mean to the lowest. Mean, median, and mode as well as the standard deviation of the mean are given for each answer.

${ }^{\mathrm{y}}$ Ratings ranged from $1=$ not at all important to $7=$ very important.

selected street segments. Completed surveys were returned directly to researchers at The Ohio State University for data entry and analysis.

Data were analyzed using SPSS+ 14.0 (SPSS Inc., Chicago, IL). Central tendencies were determined for all items and summated scales. Tests were run including $t$ tests, analyses of variance (ANOVAs), and Cramer's V for significance and relationship.

\section{Respondents}

\section{RESULTS AND DISCUSSION}

Because the survey was administered by the city of Toledo, Ohio, the researchers do not have access to the frame and cannot

Table 2. Residents were questioned about the trees lining their street and asked how important these reasons were to them in determining the appeal of their street. ${ }^{z}$

\begin{tabular}{|c|c|c|c|c|}
\hline Reasons regarding street trees & Mean $^{y}$ & $\begin{array}{l}\text { Standard } \\
\text { deviation }\end{array}$ & Median & Mode \\
\hline They make the street prettier & 6.26 & 1.04 & 7 & 7 \\
\hline $\begin{array}{l}\text { The shade cools the street and } \\
\text { the homes }\end{array}$ & 6.22 & 0.92 & 7 & 4 \\
\hline $\begin{array}{l}\text { The way the trees stretch over } \\
\text { the street is inviting }\end{array}$ & 6.16 & 1.13 & 7 & 7 \\
\hline The large size of the trees & 5.67 & 1.35 & 6 & 7 \\
\hline The color in the fall & 5.67 & 1.31 & 6 & 6 \\
\hline $\begin{array}{l}\text { They increase my property's } \\
\text { value }\end{array}$ & 5.39 & 1.52 & 6 & 7 \\
\hline They reduce wind & 5.19 & 1.59 & 5 & 7 \\
\hline They lower utility bills & 5.06 & 1.69 & 5 & 5 \\
\hline $\begin{array}{l}\text { The look of the trunk and } \\
\text { branches in the winter }\end{array}$ & 4.78 & 0.92 & 5 & 5 \\
\hline They are all the same size & 3.95 & 1.80 & 4 & 4 \\
\hline They are all alike & 3.81 & 1.78 & 4 & 4 \\
\hline Each tree is different & 3.70 & 1.74 & 4 & 4 \\
\hline $\begin{array}{l}\text { They help make a neighborhood } \\
\text { feel safe }\end{array}$ & 3.69 & 1.67 & 4 & 6 \\
\hline
\end{tabular}

${ }^{\mathrm{z}}$ Answers are ranked from highest mean to the lowest. Mean, median, and mode as well as the standard deviation of the mean are given for each answer.

${ }^{\mathrm{y}}$ Ratings ranged from $1=$ does not relate to $7=$ major reason. 
Table 3. The following questions asked how residents might value the following characteristics of trees on their street. ${ }^{z}$

\begin{tabular}{|c|c|c|c|c|}
\hline Abbreviated characteristics & Mean $^{y}$ & $\begin{array}{l}\text { Standard } \\
\text { deviation }\end{array}$ & Median & Mode \\
\hline Strong branches & 6.00 & 1.48 & 7 & 7 \\
\hline $\begin{array}{l}\text { The size of the trees as they } \\
\text { mature }\end{array}$ & 5.78 & 1.47 & 6 & 7 \\
\hline $\begin{array}{l}\text { The way the trees stretch across } \\
\text { the street }\end{array}$ & 5.73 & 1.48 & 6 & 7 \\
\hline Color of the leaves in the fall & 5.62 & 1.45 & 6 & 6 \\
\hline $\begin{array}{l}\text { Various shades of green of } \\
\text { different trees }\end{array}$ & 5.05 & 1.76 & 5 & 6 \\
\hline Flowers or blooms & 4.87 & 1.58 & 5 & 5 \\
\hline Dense foliage (leaves) & 4.78 & 1.64 & 5 & 6 \\
\hline Texture of the leaves & 4.11 & 1.84 & 4 & 5 \\
\hline Large leaves & 4.05 & 1.72 & 4 & 4 \\
\hline Small leaves & 3.80 & 1.70 & 4 & 4 \\
\hline Showy bark for winter & 3.65 & 1.75 & 4 & 4 \\
\hline Small or unimportant fruit & 2.70 & 1.63 & 3 & 1 \\
\hline Large or showy fruit & 2.69 & 1.60 & 3 & 1 \\
\hline
\end{tabular}

${ }^{\mathrm{z}}$ Answers were ranked from highest mean to the lowest. Mean, median, and mode as well as the standard deviation of the mean are given for each answer.

${ }^{y}$ Ratings ranged from $1=$ not at all important to $7=$ completely.

therefore identify response rate. The city estimated that there were 384 addresses in the area surveyed, but this includes addresses for vacant lots, properties using cross streets as mailing addresses, and additional addresses for properties with more than one lot. The city received 89 questionnaires as undeliverable, whereas 113 usable survey instruments were returned. This would then account for at least $50 \%$ of the estimated 384 initial mailings by the city.

Fully $100 \%$ of the respondents owned their homes, so that variable was removed from further analysis. The median years living in the home was 11 and the mean was 16.4. This suggests that a resident's average time in their home was similar to the 15-year national,16-year Ohio, and 18-year Toledo area averages for owner-occupied residences (J. Butler, U.S. Department of Commerce, U.S. Census Bureau, pers. comm.). A minority of the families $(38 \%)$ have children under 18 years of age living at home. There were no statistically significant correlations between length of time in residence with any of the concerns about trees. Concerns are thus felt to be valid across ages and stages of life. Furthermore, the $t$ test did not reveal any differences in tree concerns for households with children under 18 years of age.

\section{Neighborhood Characteristics}

Residents were asked what they liked about their street (Table 1). Respondents identified safety, cleanliness, attractiveness, and value of the houses as the things most important to liking their neighborhood. All items in the scale (with a reliability of 0.79 ), however, were rated highly with a summated mean for "liking the neighborhood" at 5.91. Table 1 is a chart identifying the responses to the various elements.

Not surprisingly, there was a significant relationship (using an ANOVA) between households with children under 18 and the amount of traffic $(P=0.0080)$ and a good area for children to play $(P=0.000)$. Feeling safe was also significantly correlated to the amount of traffic $(\mathrm{r}=0.478)$ and being a good area for children to play $(\mathrm{r}=0.232)$. Low traffic density reduces risk to children at play. Trees have been shown to be associated with
Table 4. Residents were questioned regarding their attitudes toward maintenance concerns associated with trees on their street. ${ }^{z}$

\begin{tabular}{lllll}
\hline Street tree concerns & Mean $^{\mathrm{y}}$ & $\begin{array}{l}\text { Standard } \\
\text { deviation }\end{array}$ & Median & Mode \\
\hline $\begin{array}{l}\text { the way the tree roots (damage } \\
\quad \text { to sidewalks) }\end{array}$ & 5.11 & 1.71 & 5 & 7 \\
$\begin{array}{l}\text { Seeds and seedlings from the } \\
\quad \text { tree }\end{array}$ & 3.94 & 2.11 & 4 & 1 \\
$\begin{array}{l}\text { Maintenance of the trees on my } \\
\quad \text { tree lawn }\end{array}$ & 3.68 & 2.02 & 4 & 4 \\
$\begin{array}{l}\text { Raking leaves in the fall } \\
\text { Summated mean }\end{array}$ & 3.32 & 1.86 & 4 & 1 \\
$\quad$
\end{tabular}

${ }^{\mathrm{z}}$ Answers were ranked from highest mean to the lowest. Mean, median, and mode as well as the standard deviation of the mean are given for each answer.

${ }^{\mathrm{y}}$ Ratings ranged from $1=$ not at all important to $7=$ serious concern.

reduced crime in some low-income communities (Kuo 2001). It was interesting but not surprising to see this concern expressed in this neighborhood as well.

Running a Cramers' V, there were several items within the scales that did correlate significantly. The item of "knowing my neighbors" was slightly to moderately strongly correlated to all the variables related to street or neighborhood appreciation with the exceptions of value of the houses and attractiveness of the street. This was the item that had the lowest mean, median, and mode scores. Still, knowing neighbors is important in determining an individual's feeling toward his or her neighborhood and interrelates with most other elements in determining how people view their neighborhood.

Overall, correlations among variables ranged from 0.014 (negligible) to 0.651 (strong). Style of homes was weakly to moderately correlated to proximity to necessities ( $\mathrm{r}=0.203, P=$ $0.031)$, value of the houses $(\mathrm{r}=0.421, P=0.000)$, attractiveness of the street $(\mathrm{r}=0.262, P=0.005)$, mature trees on the street $(\mathrm{r}=0.264, P=0.005)$, landscaping $(\mathrm{r}=0.363, P=$ $0.000)$, and cleanliness of the street $(\mathrm{r}=0.298, P=0.001)$.

A separate item asked specifically "Overall, do you like the street you live on?" Responses ranged from $1=$ not at all to $7=$ very much. The mean was very strong at 6.19 with a deviation of 0.967 . This item, however, was only significantly correlated with the summated mean of the above scale, "the neighbors" ( $\mathrm{r}=0.323 . P=0.001)$, and "knowing the neighbors" ( $\mathrm{r}=0.224, P=0.019)$. These findings would suggest that when asked about specifics, individuals view different elements of why they like their streets as discreet elements and respond differently. Yet, overall, there is consistency in the composite response but no correlation in the individual score.

Interestingly, landscaping people have in front of their houses was more uniformly related to characteristics of street trees (Table 2): helping to make a neighborhood feel safe $(0.187, P=$ $0.000)$, cooling the street/homes $(0.386, P=0.000)$, reducing wind $(0.324, P=0.000)$, tree canopies over the street $(0.320$, $P=0.000)$, larger-sized trees $(0.410, P=0.000)$, increased property values $(0.483, P=0.000)$, lower utility bills $(0.331$, $P=0.000)$, make the street prettier $(0.503, P=0.000)$, the same size $(0.312, P=0.000)$, and color in the fall $(0.358, P=0.000)$ were considered as being related to front yard landscaping.

\section{Street Tree Characteristics}

Respondents then were asked what they value about the trees on their street on a 13-item, 7-point Likert-type scale with a reli- 
ability of 0.86 . Responses ranged from $1=$ "doesn't relate" to 7 = "major reason" (Table 2). Several items were viewed as near the midpoint: helping making the neighborhood feel safe, looking alike, being the same size, and being different. All other items were viewed positively with making the street prettier being the most strongly supported item followed closely by cooling the street and the homes and the way they stretch over the street.

In correlating the elements of what people think about the trees on their streets with characteristics of their neighborhood, several patterns emerge. Attractiveness of the street was moderately strongly and significantly related to mature trees on the street ( $\mathrm{r}=0.530, P=0.000)$, landscaping people have in front of their houses $(\mathrm{r}=0.573, P=0.000)$, and cleanliness of the street ( $\mathrm{r}=0.566, P=0.000)$. It is interesting to note that feelings about trees are influenced by larger issues related to the neighborhood.

Mature trees on the street were also significantly related to many desirable characteristics of trees. Shade that cools streets and homes $(0.321, P=0.000)$, the way trees stretch over the street $(0.385, P=0.000)$, and the large size of the trees $(0.468$, $P=0.000)$ are all characteristics of mature trees. Increased property values $(0.442, P=0.000)$ and lowering utility bills $(0.375, P=0.000)$ are also a function of maturity. Aesthetic characteristics such as making the street prettier $(\mathrm{r}=0.391, P=$ $0.000)$, color in the fall $(\mathrm{r}=0.290, P=0.002)$, and the trees are the same size ( $\mathrm{r}=0.227, P=0.016)$ were also correlated with maturity.

Street trees were neutrally associated with making the community feel safe despite research in Illinois that associates trees and grass with reduced domestic violence and fewer police calls (Kuo 2001). This particular community did not perceive a strong connection with this benefit of trees and this finding would beg further research in perceptions of safety (embedded like in this scale or explicit as a question).

\section{Positive Individual Tree Characteristics}

Respondents were asked 13 items about how much they valued specific elements of trees that might reveal those characteristics that might appeal in selecting replacement trees (Table 3). Responses on the 7-point Likert-type scale ranged from $1=$ "not at all" to $7=$ "completely." This scale had a reliability of 0.89 . From this scale, it becomes clear that there is less agreement on characteristics that influence a majority of homeowners. Clearly, fruit (large or showy and small or unimportant) were not desirable for most of the respondents with mean scores of 2.69 and 2.70 and medians of 3 and modes of 1 . Several items were neutral in both median and mode (4): showy bark for winter (3.65), large leaves (4.11), and small leaves (3.80). Results suggest that bark and leaf size is relatively unimportant compared with other elements. Likewise, texture of the leaves had a minimally positive mean of 4.11 and a neutral median of 4 , but a mode of 5 .

By far, the most desirable characteristic in the view of respondents in this neighborhood is strong branches with a mean of 6 and median/modes of 7 . Also, positive characteristics were (in descending order), the size of the trees as they mature, the way the trees stretch across the street, the color of the leaves in the fall, the various shades of green of different trees, and the dense foliage. Here we see a preference for large trees as was noted by Schroeder and Ruffolo (1996) in the Midwest. It seems reason- able to accept the conclusion of Schroeder et al. (2006) that higher latitudes, cooler summer temperatures, and lower sun angles are involved.

In correlational analysis, color of leaves in the fall relates at a statistically significant level $(P<0.001)$ to all other aesthetic individual characteristics. Fall color also correlates to all items on the "trees on my street" scale at moderately weak to strong levels. One correlation was expected (e.g., large to small fruit $r$ $=0.736, P=0.000$ ). Aesthetic elements of shades of green, showy bark, dense foliage, and texture of the leaves all had moderate to moderately strong statistically significant correlations. There seems less concern for specific aesthetic characteristics such as foliage color, texture, showy bark, and foliage density despite the fact that trees are often marketed for such characteristics. Thus, it would appear that residents would not be concerned about a mix of tree species with varying aesthetic characteristics on their street.

\section{Negative Individual Tree Characteristics}

There are some maintenance concerns about trees along the street and to get at this, four very common criticisms were presented and respondents were asked the degree to which each of these is a serious concern (Table 4). Responses ranged from $1=$ "not at all" to $7=$ "serious concern." The scale had a reliability of 0.89 .

In general, there were limited concerns about raking (3.32 with a mode of 1). Maintenance of the trees, as well as seeds and seedlings, were close to neutral at 3.94 but again with a mode of 1. Clearly, the largest concern was the damage to sidewalks from tree roots, which had a mode of 7 and a mean of 5.11. Overall, negative characteristics were viewed as neutral with a summated mean of 4.01 .

All items regarding negative characteristics of trees are strongly and significantly correlated at the $P<0.001$ level. Maintenance concern correlations with desirable characteristics are more revealing. Maintenance concerns correlate statistically with cleanliness of the street and flowers or blooms, especially in terms of seeds and seedlings, maintenance of the tree, and damage to sidewalks. Clearly, residents see a potential downside to some aesthetic benefits.

\section{CONCLUSIONS}

Selecting large replacement trees that are attractive and provide an array of summer and fall colors, textures, and densities will ultimately be the characteristics that satisfy most respondents. Residents liked the large trees that make the neighborhood seem more mature. Such trees need to be trees that will grow to a size sufficient to arch across the street and provide the shade valued by residents. This is consistent with Schroeder's work comparing attitudes toward street trees in the United States and the United Kingdom where U.S. residents preferred larger trees (Schroeder et al. 2006).

There might be consideration given to a mix of faster-growing trees and larger, long-lived trees that may be slower to mature, because residents most value the shade provided by the trees and the various values related to the shade. Variations in foliage colors in both summer and fall were valued. Downtown Chicago has an interesting practice of planting no more than three trees of the same species in a row. Chicago's practice seems as if it would meet the resident's desires as expressed in their responses. A mixture of species would also provide additional species di- 
versity that might reduce the impact of another exotic pest that might again kill large numbers of trees in this neighborhood in the future.

Replacements might precede cutting of old trees to satisfy the need for trees adding to the quality of the street. In a situation such as EAB in which the pest might not be identified until the pest is established, the community may not have time to respond. Furthermore, many community budgets are stretched thin and the community might tend to delay action until the impact is apparent, which is now known to be 4 years or more after a tree is first attacked by EAB. Some aggressive and forward-looking Ohio communities have adopted an ash replacement program before the pest is identified in their community and are removing some ash each year.

Safety is an interesting issue in urban forestry. This was one of the concepts most strongly associated with positive feelings toward their street and neighborhood. Despite prior research showing trees assist in improving safety and the perception of safety, trees were neutrally associated with safety in this particular study. Perhaps urban foresters might try to reinforce these concepts as they begin to try to develop support for their programs. It would appear that this benefit is not well-known but might assist urban foresters as they compete with other agencies. Another issue might be the degree to which safety is embedded among other issues like in this study or viewed as a separate topic, which could alter the findings. Additional research is needed in this arena.

There are consistent concerns about cleanliness of the street related to trees. Damage to sidewalks and subsequent maintenance are concerns in Toledo, like in many communities. Interestingly, leaves do not appear to be an issue; perhaps Toledo's pickup program or resident's simple acceptance of fall leaf drop accounts for this. However, fruits, seedlings, twigs, branches, and trees that do not have strong branch attachments do appear to be considered problematic.

\section{LITERATURE CITED}

Akiyama, K., and S. Ohmomo. 2000. The Buprestid Beetles of the World. Iconographic Series of Insects 4. Gekkan-Mushi Co. Ltd., Tokyo, Japan. 341 pp.

Bonnes, M., G. Carrus, M. Bonaiuto, F. Fornara, and P. Passafaro. 2004. Inhabitant's environmental perceptions in the city of Rome within the framework for urban biosphere reserves of the UNESCO Programme on Man and Biosphere. Annals of the New York Academy of Sciences 1023:175-186.

Cappaert, D., D.G. McCullough, T.M. Poland, and N.W. Siegert. 2005. Emerald ash borer in North America: A research and regulatory challenge. American Entomologist 51:152-163.

Cheng, S., and J. McBride. 2006. Restoration of the urban forests of Tokyo and Hiroshima following World War II. Urban Forestry and Urban Greening 5:155-168.

Fraser, E.D., and W.A. Kenney. 2000. Cultural background and landscape history as factors affecting perceptions of the urban forest. Journal of Arboriculture 26:107-113.

Herms, D.A., D.G. McCullough, and D.R. Smitley. 2004. Under attack: The current status of the emerald ash borer infestation and the program to eradicate it. American Nurseryman 200:20-27.

Hitchmough, J.D., and A.M. Bonugli. 1997. Attitudes of a medium sized town in south west Scotland to street trees. Landscape Research 22:327-337.

Iverson, L., A. Prasad, J. Bossenbroek, D. Sydnor, and E. Schwartz. 2006. Modeling potential movements of the emerald ash borer in Ohio and Michigan. Proceedings of the 2006 Society of American Foresters National Convention.
Johnston, M., and L. Shimada. 2004. Urban forestry in a multicultural society. Journal of Arboriculture 30:185-191.

Kalmbach, K.L., and J.J. Kielbaso. 1979. Resident attitudes toward selected characteristics of street tree plantings. Journal of Arboriculture 5:124-129.

Kuo, F.E. 2001. Coping with poverty: Impacts of environment and attention in the inner city. Environment and Behavior 33:5-34.

Martin, C.A., P. Warren, and A. Kinzig. 2004. Neighborhood socioeconomic status is a useful predictor of perennial landscape vegetation in residential neighborhoods and embedded small parks in Phoenix, AZ. Landscape and Urban Planning 69:355-368.

McPherson, E.G. 2005. Trees with benefits. American Nurseryman 201: 34-40.

Poland, T.M., and D.G. McCullough. 2006. Emerald ash borer: Invasion of the urban forest and the threat to North America's ash resource. Journal of Forestry 104:118-124.

Schroeder, H., J. Flannigan, and R. Coles. 2006. Residents' attitudes toward street trees in the U.K. and U.S. communities. Arboriculture and Urban Forestry 32:236-246.

Schroeder, H.W., and W.N. Cannon Jr. 1983. The esthetic contribution of trees to residential streets in Ohio towns. Journal of Arboriculture 9:237-243.

Schroeder, H.W., and S.R. Ruffolo. 1996. Householder evaluations of street trees in a Chicago suburb. Journal of Arboriculture 22:35-43.

Sommer, R., P.A. Barker, H. Guenther, and K. Kurani. 1989. Householder evaluation of two street tree species. Journal of Arboriculture 15:99-103.

Sydnor, T.D., M. Bumgardner, and A. Todd. 2007. The potential impacts of emerald ash borer (Agrilus planipennis) on Ohio, U.S., communities. Arboriculture and Urban Forestry 33:48-54.

United States Department of Agriculture, Animal Plant Health Inspection Service. 2003. Emerald ash borer; quarantine and regulations. Federal Register 66:59082-59091.

Joseph Heimlich

Professor of Environmental Education

School of Environment and Natural Resources

The Ohio State University

2021 Coffey Road

Columbus, OH 43210, U.S.

T. Davis Sydnor (corresponding author)

Professor of Urban Forestry

School of Environment and Natural Resources

The Ohio State University

2021 Coffey Road

Columbus, OH 43210, U.S.

sydnor.1@osu.edu

Matthew Bumgardner

Research Forest Products Technologist

USDA Forest Service

359 Main Road

Delaware, $\mathrm{OH} 43015$, U.S.

Patrick O'Brien

Urban Forester

Forestry Division

City of Toledo

Toledo, $\mathrm{OH} 43607$, U.S.

Résumé. Des résidants de quatre rues de Toledo composées d'arbres matures, incluant des frênes dont l'abattage était planifié en raison d'une infestation par l'agrile du frêne, ont été sondés pour connaître leur opinion face aux arbres de rues. Toledo est en voie d'abattre environ 
5000 arbres. Les arbres à grand déploiement avec une variété de caractéristiques foliaires en été et en automne étaient fortement valorisés, suggérant de ce fait que les résidants allaient être satisfaits avec un mélange d'espèces plutôt que de planter une seule espèce sur chaque rue. Le fait que les cimes puissent recouvrir entièrement la rue était aussi un aspect important pour les résidants et cela est une caractéristique importante des grands arbres urbains de rues. Les résidants allaient être satisfaits si les arbres de remplacement pouvaient être plantés avant l'abattage des arbres existants. La présence de fleurs ne constituait pas un aspect significatif pour les résidants. À Toledo, tout comme dans de nombreuses communautés, le principal objet de préoccupation en regard des arbres dans le cadre de cet inventaire était le risque potentiel de dommages aux trottoirs piétonniers.

Zusammenfassung. In Toledo wurden die Einwohner von vier Straßen mit großen Straßenbäumen inkl. für eine Fällung vorgesehenen Eschen wegen eines Befalls mit EAB danach befragt, was sie für eine Einstellung zu den Bäumen haben. Toledo ist grade dabei, 5.000 Bäume zu entfernen. Große Bäume mit einer Vielzahl an Sommer und Herbstblatt-Charakteristika werden hoch bewertet, was bedeutet, dass die Anwohner mit einer Artenvielfalt mehr zufrieden sind, als mit einer Baumart pro Straßenzug. Die Tatsache, dass die Bäume die Straße be- schatten, war ebenfalls wichtig für die Anwohner und ist ein wichtiges Kriterium von großen Straßenbäumen. Den Anwohnern wäre es sehr angenehm, wenn vor der Entfernung erstmal neue Bäume gepflanzt würden. Blumen waren dagegen nicht so besonders wichtig. In Toledo sowie in vielen anderen Kommunen ist die größte Sorge der Anwohner der mögliche Schaden am Straßenbelag durch Baumwurzeln.

Resumen. Fueron encuestados los residentes de Toledo, en cuatro calles en un área con árboles maduros, incluyendo fresnos programados para la remoción debido al ataque por EAB, para determinar sus actitudes hacia los árboles urbanos. Toledo está en el proceso de remover cerca de 5,000 árboles. Los grandes árboles con una variedad de características foliares de verano y otoño fueron altamente evaluados, sugiriendo que los residentes estarán satisfechos con una mezcla de especies antes que la plantación de cada calle con una misma especie. El hecho de que la copa de sus árboles cubra toda la calle fue también importante para los residentes y es característico de los grandes árboles urbanos. Los residentes estarían a gusto si los reemplazos fueran plantados antes de remover los árboles existentes. Las flores no fueron una preocupación para los residentes. En Toledo así como en muchas comunidades, la preocupación primaria de mantenimiento en relaciones con los árboles es el daño potencial a las aceras.

\section{APPENDIX 1 SURVEY INSTRUMENT AS DISTRIBUTED}

\section{My Street}

There are many things that lead one to "like" their neighborhood and specifically their street. Below are a wide variety of reasons. For each, how important is this to you in terms of the street you live on? If it is not at all important or not applicable, you would circle a 1. If it is a very important reason, you would circle 7 . If it is moderately important, you would circle a 4, 5, or 6.

\begin{tabular}{|c|c|c|c|c|c|c|c|}
\hline \multirow[b]{2}{*}{ The neighbors } & \multicolumn{5}{|c|}{ Not at all important } & \multicolumn{2}{|c|}{ Very important } \\
\hline & 1 & 2 & 3 & 4 & 5 & 6 & 7 \\
\hline The style of houses/homes/apartments & 1 & 2 & 3 & 4 & 5 & 6 & 7 \\
\hline Feeling safe & 1 & 2 & 3 & 4 & 5 & 6 & 7 \\
\hline The amount of traffic & 1 & 2 & 3 & 4 & 5 & 6 & 7 \\
\hline Being a good area for children to play & 1 & 2 & 3 & 4 & 5 & 6 & 7 \\
\hline The proximity to necessities (groceries, stores) & 1 & 2 & 3 & 4 & 5 & 6 & 7 \\
\hline The attractiveness of the street & 1 & 2 & 3 & 4 & 5 & 6 & 7 \\
\hline The mature trees on the street & 1 & 2 & 3 & 4 & 5 & 6 & 7 \\
\hline The landscaping people have in front of their houses & 1 & 2 & 3 & 4 & 5 & 6 & 7 \\
\hline \multirow[t]{2}{*}{ The cleanliness of the street } & 1 & 2 & 3 & 4 & 5 & 6 & 7 \\
\hline & \multicolumn{5}{|c|}{ Not at all } & \multicolumn{2}{|c|}{ Very much } \\
\hline Overall, do you like the street you live on? & 1 & 2 & 3 & 4 & 5 & 6 & 7 \\
\hline
\end{tabular}

Think about the trees lining your street. There are various reasons people like having trees on a street, and some of them are listed below. How strongly do you feel each reason relates to how the trees on your street appeal to you; this time, the scale ranges from 1 being does not relate to me to 7 being a major reason you like the trees on your street.

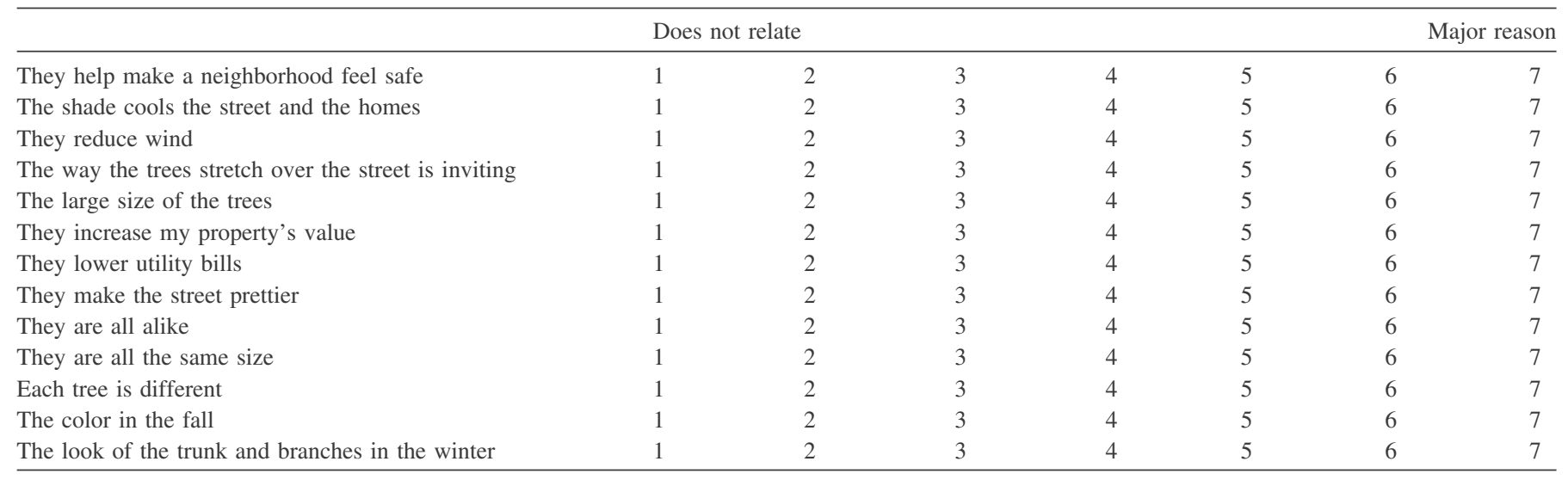




\section{APPENDIX 1 (continued) SURVEY INSTRUMENT AS DISTRIBUTED}

\section{My Street}

This series of items relates to the things you value about trees on your street. For each characteristic, how strongly do you value that particular element? 1 would be not at all and 7 would be you completely value it.

\begin{tabular}{|c|c|c|c|c|c|c|c|}
\hline \multirow[b]{2}{*}{ Flowers or blooms } & \multicolumn{6}{|c|}{ Not at all } & Completely \\
\hline & 1 & 2 & 3 & 4 & 5 & 6 & 7 \\
\hline Large or showy fruit & 1 & 2 & 3 & 4 & 5 & 6 & 7 \\
\hline Small or unimportant fruit & 1 & 2 & 3 & 4 & 5 & 6 & 7 \\
\hline Showy bark for winter & 1 & 2 & 3 & 4 & 5 & 6 & 7 \\
\hline Large leaves & 1 & 2 & 3 & 4 & 5 & 6 & 7 \\
\hline Small leaves & 1 & 2 & 3 & 4 & 5 & 6 & 7 \\
\hline Dense foliage (leaves) & 1 & 2 & 3 & 4 & 5 & 6 & 7 \\
\hline Texture of the leaves & 1 & 2 & 3 & 4 & 5 & 6 & 7 \\
\hline Color of the leaves in the fall & 1 & 2 & 3 & 4 & 5 & 6 & 7 \\
\hline Various shades of green of different trees & 1 & 2 & 3 & 4 & 5 & 6 & 7 \\
\hline The way the trees stretch across the street & 1 & 2 & 3 & 4 & 5 & 6 & 7 \\
\hline The size of the trees as they mature & 1 & 2 & 3 & 4 & 5 & 6 & 7 \\
\hline Strong branches & 1 & 2 & 3 & 4 & 5 & 6 & 7 \\
\hline
\end{tabular}

There are some maintenance concerns about trees along the street. To what degree are each of these of concern to you, from not at all (1) to a serious concern (7)?

\begin{tabular}{|c|c|c|c|c|c|c|c|}
\hline \multirow[b]{2}{*}{ The way the tree roots (damage to sidewalks) } & \multicolumn{5}{|c|}{ Not at all } & \multicolumn{2}{|c|}{ Serious Concern } \\
\hline & 1 & 2 & 3 & 4 & 5 & 6 & 7 \\
\hline Raking leaves in the fall & 1 & 2 & 3 & 4 & 5 & 6 & 7 \\
\hline Seeds and seedlings from the tree & 1 & 2 & 3 & 4 & 5 & 6 & 7 \\
\hline Maintenance of the trees on my tree lawn & 1 & 2 & 3 & 4 & 5 & 6 & 7 \\
\hline \multicolumn{8}{|l|}{ Finally, just a little bit about your household: } \\
\hline \multicolumn{2}{|l|}{ Do you: } & \multicolumn{2}{|c|}{ Own } & \multicolumn{2}{|c|}{ Rent } & & \\
\hline \multicolumn{2}{|c|}{ You have lived in your house: } & \multicolumn{2}{|c|}{ years } & & & & \\
\hline \multicolumn{2}{|c|}{ Are there children under 18 years of age in your household? } & \multicolumn{2}{|c|}{ Yes } & \multicolumn{2}{|c|}{ No } & & \\
\hline
\end{tabular}

